\title{
Review Article \\ The Role of PPARs in the Endothelium: Implications for Cancer Therapy
}

\author{
David Bishop-Bailey and Karen E. Swales \\ Translational Medicine and Therapeutics, William Harvey Research Institute, Barts and The London School of Medicine and \\ Dentistry, Queen Mary University London, Charterhouse Square, London EC1M 6BQ, UK \\ Correspondence should be addressed to David Bishop-Bailey, d.bishop-bailey@qmul.ac.uk
}

Received 10 March 2008; Revised 28 July 2008; Accepted 9 September 2008

Recommended by Dipak Panigrahy

The growth and metastasis of cancers intimately involve the vasculature and in particular the endothelial cell layer. Tumours require new blood vessel formation via angiogenesis to support growth. In addition, inflammation, coagulation, and platelet activation are common signals in the growth and metastasis of tumour cells. The endothelium plays a central role in the homeostatic control of inflammatory cell recruitment, regulating platelet activation and coagulation pathways. PPAR $\alpha,-\beta / \delta$, and $-\gamma$ are all expressed in endothelial cells. This review will discuss the roles of PPARs in endothelial cells in relation to angiogenesis, inflammation, coagulation, and platelet control pathways. In particular, we will discuss the recent evidence that supports the hypothesis that $\operatorname{PPAR} \alpha$ and $\operatorname{PPAR} \gamma$ are antiangiogenic receptors, while $\operatorname{PPAR} \beta / \delta$ is proangiogenic.

Copyright (c) 2008 D. Bishop-Bailey and K. E. Swales. This is an open access article distributed under the Creative Commons Attribution License, which permits unrestricted use, distribution, and reproduction in any medium, provided the original work is properly cited.

\section{IMPORTANCE OF THE ENDOTHELIAL CELL IN CANCER}

Endothelial cells play critical roles in vascular biology, being both the protective inner lining of vessels and the local site for delivery of oxygen to all tissues. It has become clear, particularly from the seminal work of Professor Judah Folkman, whom this issue is dedicated to, that the endothelium plays a critical role in the growth and spread of cancer [1-4]. The growth of tumours, or indeed any tissue growth requires new blood vessel formation to sustain it. This process of angiogenesis as a target for modulating cancer growth has been a major research theme. The critical initial stimulus for angiogenesis appears to be hypoxia in the growing tumour. The hypoxia leads to upregulation of hypoxia-induced transcription factors, for example, hypoxia inducible factor (HIF) $-1 \alpha$ and HIF- $2 \alpha$ [5-8], which stimulate the expressions of genes involved in oxygen homeostasis, and secretion of proangiogenic mediators such as vascular endothelial growth factor (VEGF) and basic fibroblast growth factor (bFGF) [4, $9,10]$. Although these are key growth factors for endothelial cell growth and morphogenesis, it is clear that there are an increasing number of endogenous proangiogenic factors
(PGDF, IL-8, angiopoietin-1, leptin, matrix metalloproteinases, thrombin, plasminogen activators) and antiangiogenic factors (endostatin, angiostatin, thrombospondin-1, angiopoietin-2, IL-4, IL-12, IL-18, tissue inhibitor of MMPs, TGF- $\beta$, IFN $\alpha,-\beta$, and $-\gamma)[1,4,10,11]$. When the cumulative actions of the proangiogenic mediators outweigh their antiangiogenic counterparts an "angiogenic switch" occurs [12]. In particular, VEGF (VEGF-A; $\mathrm{VEGF}_{165}$ ) is a central mediator of endothelial cell growth and angiogenesis [13]. Two endothelial VEGF tyrosine kinase receptors have been identified: VEGFR-1/Flt-1, and VEGFR-2/KDR/Flk1, with the latter being the most important in VEGF-induced mitogenesis and permeability [13]. The lymphatic system and in particular lymphangiogenesis also contributes significantly to tumour metastasis. Unlike angiogenesis, where VEGF(A) and VEGFR1/2 are key regulators, lymphangiogenesis is regulated by VEGFR-3 and VEGF-C/D isoforms (along with PROX1, podoplanin, LYVE-1, ephrinB2, and FOXC2) $[14,15]$. Once stimulated by VEGF, the receptors initiate a signal transduction cascade, activating kinases such as ERK1/2 and Akt, which phosphorylate and activate further mediators of endothelial cell proliferation, apoptosis, and angiogenesis, such as eNOS [16]. 


\begin{tabular}{|c|c|c|}
\hline Anti-angiogenic & Anti-inflammatory & \\
\hline Endostatin & Prostacyclin & \\
\hline Angiostatin & & \multirow{2}{*}{ Anti-coagulant } \\
\hline Thrombospondin-1 & IL-4, IL-12, IL-18 & \\
\hline Angiopoietin-2, & TIMPs, & \multirow{4}{*}{$\begin{array}{l}\text { Prostacyclin } \\
\text { NO } \\
\text { uPA, tPA }\end{array}$} \\
\hline IL-4, IL-12, IL-18 & TGF-b, & \\
\hline TIMPs, & & \\
\hline INF $\alpha,-\beta$, & \multirow{2}{*}{ Endothelial cell } & \\
\hline Pro-angiogenic & & Pro-coagulan \\
\hline VEGF & Pro-inflammatory & \multirow{8}{*}{$\begin{array}{l}\mathrm{PGE}_{2} \\
\text { Tissue factor } \\
\text { PAI-1 } \\
\text { Thrombin }\end{array}$} \\
\hline $\begin{array}{l}\text { bFGF } \\
\text { PGDF }\end{array}$ & $\mathrm{PGE}_{2}$ & \\
\hline IL-8 & $\mathrm{NO}$ & \\
\hline Angiopoietin-1 & Adhesion molecules & \\
\hline Leptin & Chemokines & \\
\hline Matrix metalloproteinases & $\begin{array}{l}\text { MMPs } \\
\text { Thrombin }\end{array}$ & \\
\hline Thrombin & & \\
\hline Plasminogen activators & & \\
\hline
\end{tabular}

Figure 1: The endothelial cell is the interface between the circulation and underlying tissue, and as such plays an important homeostatic role both producing and responding to a variety of pro- and antiangiogenic, inflammatory, and coagulation factors. The balance between these opposing pathways is critical in the growth, development, spread, and metastasis of tumours.

The endothelium local to the tumour itself also contributes to tumour growth and metastasis via mechanisms independent of angiogenesis. Of increasing importance is the role of chronic inflammation in tumour progression. Chronic inflammation, in particular the presence of neutrophils, macrophages, and mast cells, correlates with poor prognosis and the angiogenic state of the tumour $[17,18]$. The activation of the endothelium and its subsequent expression of adhesion molecules and chemokines is the interface for local inflammatory cell recruitment and extravasation. Central to these processes are proinflammatory transcription factors such as $\mathrm{NF} \kappa \mathrm{B}$. NF $\kappa \mathrm{B}$ regulates many inflammatory processes including inducible cytokine/chemokine and adhesion molecule expressions that are central to inflammatory cell recruitment, as well acting as a potent prosurvival signal within the cell [19].

In addition to angiogenesis and inflammation, cancer progression and metastasis is also facilitated by circulating cells and mediators regulated by the endothelium. The endothelium provides an antithrombotic surface and produces powerful antiplatelet and anticoagulant mediators such as prostacyclin, nitric oxide, and tissue- and urokinaseplasminogen activators [20]. Under physiological conditions, the endothelial surface is antithrombotic. Activated endothelial cells, however, are able to release prothrombotic/procoagulation mediators such as prostaglandin $\mathrm{PGE}_{2}$ $[21,22]$, plasminogen activator inhibitor (PAI)-1 [23], and tissue factor [23]. In cancer, thrombocytosis is common [24], suggesting that the physiological protective system usually provided by endothelial cells may be dysfunctional or overpowered by prothrombotic pathways. Driving this thrombosis may be tumour-derived thrombopoietin, and tumour- and platelet-derived growth factors and micropar- ticles [24]. The consequence of activation of the coagulation cascade in cancer progression can be seen using thrombin as an example. Thrombin activates tumour cell adhesion to platelets and endothelial cells, and induces tumour cell growth, metastasis, and angiogenesis [25].

The movement of tumour cells into and out of the circulation (or the lymphatics) involves interaction with, and crossing of, the endothelial barrier. Although tumour endothelial cells are generally highly permeable (induced by factors such as VEGF), it is still unlikely that tumour cell movement is a passive process [26]. Within the circulation, transit of tumour cells is facilitated by their interactions with activated platelets [26]. The platelets are believed to act as a shield, protecting tumour cells from both physical forces and immune-mediated killing [26].

In summary, along with angiogenesis and lymphangiogenesis, endothelial cells regulate tumour progression not only by directly interacting with tumour cells, but also by regulating local inflammatory cell recruitment, the coagulation cascade, and platelet activity. When discussing the actions of PPARs in endothelial cells it is, therefore, important to consider all these properties.

\section{PPARs AND ENDOTHELIAL CELLS}

$\operatorname{PPAR} \alpha, \operatorname{PPAR} \beta / \delta$, and PPAR $\gamma$ are expressed in endothelial cells $[27,28]$, where they regulate cell proliferation, angiogenesis, inflammation, thrombosis, and coagulation (Figure 1). PPAR $\alpha$ is expressed in human aortic endothelial cells, carotid artery endothelial cells, and human umbilical vein endothelial cells [27, 29-31]. PPAR $\gamma$ is similarly expressed in human endothelial cells both in vitro and in vivo $[27,28,31,32]$, while $\operatorname{PPAR} \beta$ is ubiquitously expressed. The role of PPAR $\gamma$ has been well characterised in endothelial cell inflammation and angiogenesis $[33,34]$. In contrast, the functions of PPAR $\alpha$ and $\operatorname{PPAR} \beta / \delta$ in endothelial cells, especially in terms of angiogenesis, are only just beginning to be understood. Indeed, although the role of PPAR $y$ will be discussed in this review, since there is considerable information on PPAR $\gamma$ in cancer [35] and an article on $\operatorname{PPAR} \gamma$ regulation of the angiogenic switch in this review series [36], this manuscript will focus more on recent observations highlighting novel roles for PPAR $\alpha$ and $\operatorname{PPAR} \beta / \delta$ in endothelial cell function and in particular on the regulation of angiogenesis. The focus of this review is the endothelial cell, but it is important to note that PPAR $\alpha$, $\beta / \delta$, and $\gamma$ expression and activity have been demonstrated in a variety of cancers, inflammatory cells [34], and in platelets [37-39]. Therefore, any effects of PPAR ligands on the development of cancer may be influenced by responses in these nonendothelial cell types as well.

\section{PPAR $\alpha$ AND PPAR $\gamma:$ ANTICANCER TARGETS IN THE ENDOTHELIUM}

\subsection{PPAR $\alpha$ and PPAR $\gamma$ ligands}

When discussing the roles of PPARs it is important to note the types of ligands potentially used in studies. Activators 
of PPAR $\alpha$ include a variety of eicosanoids, fatty acids, and synthetic compounds including the clinically used dyslipidemic drugs, the fibrates (gemfibrozil, fenofibrate, bezafibrate, ciprofibrate) $[40,41]$. Similarly, PPAR $\gamma$ activators also include a variety of eicosanoids, fatty acids, and synthetic compounds including the clinically used insulin sensitising thiazolidinedione drugs (rosiglitazone, pioglitizone, troglitizone (now withdrawn) [40, 41]. (See Figures 2 and 3.)

\subsection{PPAR $\alpha$ and PPAR $\gamma$ in cancer}

One early observation regarding $\operatorname{PPAR} \alpha$ activation by peroxisome proliferators was the induction of hepatocarcinogenesis in rodents; an effect absent in $\operatorname{PPAR} \alpha(-/-)$ knockout mice $[42,43]$. Although there has been a considerable amount of interest in the field, especially as the $\operatorname{PPAR} \alpha$ activating fibrates are in clinical use, there is no evidence that long-term activation of $\operatorname{PPAR} \alpha$ in nonrodent species including man is linked to hepatocarcinogenesis $[42,43]$.

In extrahepatic tissues, there have been fewer studies regarding PPAR $\alpha$ and cancer. Initially, it was suggested that PPAR $\alpha$ may prevent skin cancer $[44,45]$. However, topical PPAR $\alpha$ agonists were only moderately protective against tumour promotion in mouse skin, despite the upregulation of PPAR $\alpha$ in tumours compared to normal epidermis [46]. Recent studies have revealed that PPAR $\alpha$ is commonly expressed in tumour cell lines, including lung, liver, leukaemia, prostate, pancreas, bladder, colon, glioblastoma, hemangioma, melanoma, ovarian, and breast [47-49]. PPAR $\alpha$ ligands inhibit the growth of colon, breast, endometrial, and skin cells in vitro [46, 48, 50-52] and human ovarian cancer [53], melanoma, lung carcinoma, glioblastoma, and fibrosarcoma [48]. PPAR $\alpha$ ligands also decrease tumour development in colon carcinogenesis [52] and inhibit melanoma cell metastasis in vitro and in vivo $[50,54]$.

PPAR $y$ is expressed in prostate, thyroid, colon, breast and hepatocellular carcinoma, gastric, pancreatic and lung cancer, neuroblastoma, astrocytoma, and glioma, where the receptors' ligands are antiproliferative and proapoptotic [35]. It is beyond the scope of this review to discuss all the findings of PPAR $\gamma$ in cancer, and there are a number of excellent reviews in the field $[33,35,55,56]$ including one on PPAR $\gamma$ and angiogenesis in this series [36].

The majority of the evidence points towards PPAR $\gamma$ ligands suppressing tumourgenesis, for example, the receptors' ligands inhibit the growth of xenografts of many of the aforementioned tumours in vivo [35]. However, in colon cancer, the beneficial role for PPAR $\gamma$ agonists is controversial [57]. In the $\mathrm{APC}^{\mathrm{min}} /+$ mouse, PPAR $y$ ligands increased precancerous polyp formation and the frequency and size of tumours in the colon $[58,59]$. In contrast, heterozygous loss of PPAR $\gamma$ increases colon cancer incidence in mice [60]. This latter study corresponds with most of the available data, suggesting that PPAR $\gamma$ has antineoplastic effects in colon cancer; a point further supported in colon cancer patient studies by the detection of mutations causing loss

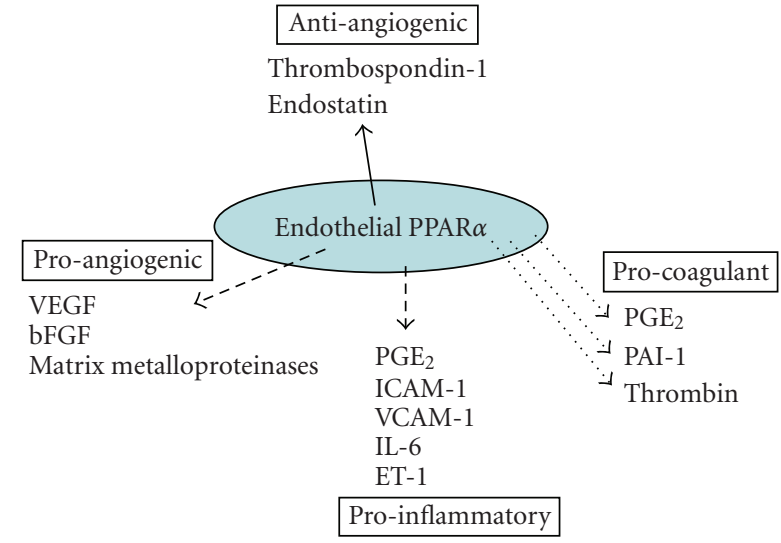

FIGURE 2: Endothelial PPAR $\alpha$ has predominantly inhibitory actions on endothelial cell activation. The majority of studies so far indicate that $\operatorname{PPAR} \alpha$ activation induces (solid line) antiangiogenic factors, while reduces (broken line) proangiogenic factors, proinflammatory pathways, and procoagulant mediator release.

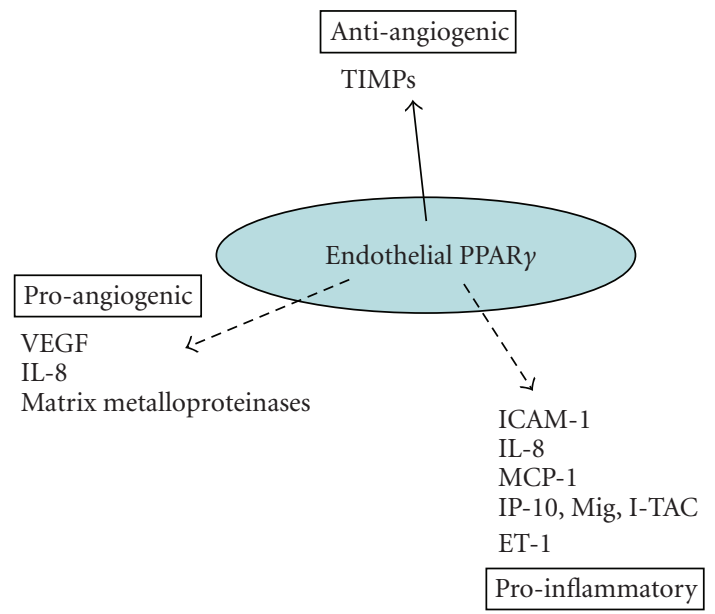

FIGURE 3: Endothelial PPAR $\gamma$ has predominantly inhibitory actions on endothelial cell activation. The majority of studies so far indicate that PPAR $\gamma$ activation inhibits (broken line) proangiogenic factors, proinflammatory pathways, and procoagulant mediator release, while inducing (solid line) antiangiogenic factors.

of function or impaired ligand binding of PPAR $\gamma$ [61] and polymorphisms of the PPAR $\gamma$ gene [62].

There have been positive results using PPAR $\gamma$ ligands to treat tumours experimentally both in vitro and in vivo, but so far this has not been successfully translated into a beneficial anticancer therapy in man. There have been a number of small scale clinical trials testing PPAR $\gamma$ ligands in cancer in man with varying success [63]. The most promising results were from small phase II studies treating prostate cancer [64] and liposarcoma patients [65] with troglitazone. In contrast, a phase II study treating liposarcoma patients with rosiglitazone did not significantly improve clinical outcome [66] and so far no beneficial effects of PPAR $\gamma$ ligands have been observed in trials for breast or colon cancer patients [35]. 


\subsection{PPAR $\alpha$ and PPAR $\gamma$ regulation of angiogenesis}

Early studies showed no effect of the selective PPAR $\alpha$ ligand WY-14643 on endothelial cell proliferation [27], however, recent studies using immortalised human dermal microvascular endothelial cells show that the PPAR $\alpha$ ligand fenofibrate inhibits endothelial cell proliferation, migration, and tube formation (on a fibrin matrix) in vitro and angiogenesis in vivo [67]. Fenofibrate acts by disrupting the formation of the actin cytoskeleton and inhibits bFGF-induced Akt activation and cyclooxygenase 2 (COX-2) gene expression [67]. Similar results were found in a porcine model of vascular remodelling after coronary artery angioplasty where fenofibrate increased lumen size and vessel area and inhibited constrictive remodelling and inflammatory cell infiltration [68]. Importantly, adventitial angiogenesis was significantly reduced by fenofibrate in the injured vessels 3 days after angioplasty [68].

In contrast to this vascular study, the investigation of PPAR $\alpha$ regulation of tumour angiogenesis has only just begun. In a recent report, Panigraphy et al. provide compelling evidence for PPAR $\alpha$ inhibition of tumour growth by targeting angiogenesis [48]. Similar to previous findings, PPAR $\alpha$ activation had direct effects on endothelial cells, inhibiting VEGF-induced endothelial cell migration in vitro and FGF2 induced corneal angiogenesis in vivo [48]. Tumour cell synthesis of VEGF and FGF2 was also suppressed by $\operatorname{PPAR} \alpha$ activation in conjunction with an increased expression of antiangiogenic thrombospondin-1 (TSP-1) [48]. In subcutaneously implanted human pancreatic cancer cells grown in mice, as well as in human prostate cancer, $\operatorname{PPAR} \alpha$ expression was detected not only in the tumour cells, but also in the new invading microvessels [48]. Systemic treatment of mice with PPAR $\alpha$ ligands inhibited the growth of melanoma, glioblastoma, and fibrosarcoma tumours implanted in vivo, which was associated with a reduction in vessel density and inflammation [48]. To dissect the mechanism by which $\operatorname{PPAR} \alpha$ suppressed tumour growth (i.e., direct effects on the tumour and/or angiogenesis), embryonic fibroblasts from $\operatorname{PPAR} \alpha(-/-)$ knockout mice were transformed with SV40 large $\mathrm{T}$ antigen and $\mathrm{H}$-ras oncogenes then implanted into wild-type and PPAR $\alpha-/-$ mice. The growth of these cells into tumours could be suppressed by $\operatorname{PPAR} \alpha$ ligands in wild-type mice only, indicating that tumour suppression by $\operatorname{PPAR} \alpha$ ligands was completely dependent on the expression of PPAR $\alpha$ in the host but not in the tumour cells [48]. Fenofibrate strongly induced the antiangiogenic factors TSP1 and endostatin in wild-type, but not PPAR $\alpha-/-$ mice, supporting the role of PPAR $\alpha$ as an antiangiogenic regulator [48]. Angiogenesis and inflammation are central processes through which the tumour interacts with its surroundings to influence tumour growth. Although this study does not rule out an anti-inflammatory effect of the PPAR $\alpha$ ligands, it is highly unlikely that the antitumour host-derived effects are due to suppression of inflammation because mice deficient in PPAR $\alpha$ generally exhibit enhanced inflammation [64].

TSP-1 is a potent angiogenesis inhibitor that targets endothelial cells for apoptosis by initiating a signalling cascade through the CD36 receptor. $\operatorname{PPAR} \alpha$ directly induces
TSP-1 and can enhance TSP-1 signalling indirectly by upregulating CD36 in the endothelium. PPAR $\alpha$ activation upregulates CD36 expression in the liver [69] and in macrophages [70]. Moreover, coadministration of PPAR $\gamma$ ligands with exogenous TSP-1 or the TSP-1 peptide derivative ABT510 synergises to suppress angiogenesis and induce endothelial cell apoptosis [71]. The improvement of the antiangiogenic efficacy of TSP-1 was attributed to PPAR $\gamma$ induced CD36 expression via a PPAR response element in the CD36 promoter $[69,71]$.

The vast majority of studies have indicated an antiangiogenic role for PPAR $\alpha$ and PPAR $\gamma$ in a variety of models. However, it is important to note that the VEGF promoter contains a PPAR response element and PPAR $\alpha$ and $-\gamma$ ligands can induce VEGF in certain cell types [72-75]. Moreover, in contrast to the majority of findings, a recent study suggests that both PPAR $\alpha$ and PPAR $\gamma$ ligands may also have proangiogenic properties in vitro in an endothelial/interstitial cell coculture assay and in a murine corneal angiogenesis model in vivo [72]. The angiogenesis induced by PPAR $\alpha$ and PPAR $y$ ligands was associated with the induction of VEGF, accompanied by increased activation of AKT and eNOS (by phosphorylation) [72]. How the levels of $\operatorname{PPAR} \alpha$ - or PPAR $\gamma$ mediated angiogenesis are compared to traditional growth factor-induced angiogenesis is not known? Indeed, these results are controversial, as previous corneal angiogenesis models clearly demonstrate antiangiogenic effects of PPAR $\alpha$ and PPAR $\gamma$ ligands $[28,48,76]$.

Multiple mechanisms have been proposed by which $\operatorname{PPAR} \alpha$ and PPAR $\gamma$ regulate the changes in pro- and antiangiogenic factors. Here, we will focus on the central target for PPAR regulation of angiogenesis, the proangiogenic VEGF/VEGFR signalling pathway. PPAR $\gamma$ can downregulate VEGF either directly through a PPAR response element within the VEGF promoter [77] or by decreasing $\mathrm{PGE}_{2}$, an endogenous stimulator of angiogenesis [78]. PPAR $\gamma$ can also decrease VEGF responses by suppressing transcription of its receptor VEGFR2, by interacting with and preventing Sp1 binding to DNA [79].

In colorectal cancer cell lines, $\operatorname{PPAR} \alpha$ also inhibits the transcription factor AP-1, impairing its binding to response elements in the VEGF and COX-2 genes and inhibiting c-jun transactivation activity, thus downregulating VEGF and COX-2 expression [80]. It is, therefore, clear that the regulation of angiogenic factors by $\operatorname{PPAR} \alpha$ and $\operatorname{PPAR} \gamma$ may be determined by cell and cancer type and the experimental models used. Much more research is required to fully understand whether PPAR activation will be pro- or antiangiogenic in specific human cancers.

\subsection{The effects of PPAR $\alpha$ and PPAR $\gamma$ on endothelial progenitor cells}

Endothelial progenitor cells (EPCs) present in peripheral blood promote angiogenesis and improve endothelial function. The research on the effects of PPARs on EPCs has focused on PPAR $\gamma$. Despite PPAR $\gamma$ generally being considered antiangiogenic, the PPAR $\gamma$ ligands rosiglitazone and pioglitazone in diabetic patients increase endothelial 
progenitor cell (EPC) number and migratory activity [81, 82]. Pioglitazone and rosiglitazone also improve the adhesive capacity of EPCs to fibronectin and collagen [82] and promote EPC colony formation, [83, 84]. In vitro, pioglitazone increased EPC proliferation, colony formation, and attenuated apoptosis [85]. Similarly, in mice pioglitazone induced the number and migratory activity of EPCs while decreasing their apoptosis, resulting in increased in vivo neoangiogenesis [86]. From these results, it has been proposed that PPAR $\gamma$ ligands may have a double-edged role in angiogenesis, with proangiogenic effects on EPCs at low-systemic concentrations and antiangiogenic effects at higher local concentrations [86]. Indeed, biphasic effects of pioglitazone were observed on EPCs in culture, when the number of EPC colonies and amount of adhesion were increased by $1 \mu \mathrm{M}$ but not $10 \mu \mathrm{M}$ [87]. This higher concentration of pioglitazone induced TGF- $\beta 1$ and its receptor endogolin, which suppress EPC function [87]. These findings have important clinical implications suggesting that the pro/antiangiogenic properties of PPAR $\gamma$ ligands may be largely dose-driven. Moreover, understanding this mechanism by which PPAR $\gamma$ may regulate both pro- and antiangiogenic pathways at least in EPCs may help to explain some of the contradictions in the studies examining the role of PPAR $\gamma$ in angiogenesis.

\subsection{Effects of PPAR $\alpha$ and PPAR $\gamma$ on endothelial cell inflammation}

The role of PPAR $\alpha$ in inflammation has been studied in animal models, particularly in wound healing and cardiovascular disease models (atherosclerosis and restenosis) [55, 56]. PPAR $\alpha$ is a negative regulator of inflammation [34] in inflammatory models. Supporting this, PPAR $\alpha-/-$ mice exhibit enhanced inflammation [88], although this may be due in part to deceased $\beta$-oxidation and accumulation of biologically active lipid mediators.

In addition to these experimental models, $\operatorname{PPAR} \alpha$ agonists decrease the expression of inflammatory markers both in human cells and patients treated with fibrates $[89,90]$. In human endothelial cells in culture, PPAR $\alpha$ ligands inhibit the cytokine/LPS induction of COX-2 [38, 69], ICAM-1 [91], VCAM-1 [29, 31], endothelin-1 [92], IL-6, and prostaglandin $\mathrm{E}_{2}[32,93]$. Similarly, PPAR $\alpha$ ligands repress thrombin-induced expression of endothelin1 [32]. The PPAR $\alpha$ ligand fenofibrate, but not the PPAR $\gamma$ ligand rosiglitazone, also reduces the induction of tissue factor in human endothelial cells [94], while PAI-1 levels remain unchanged [31]. PPAR $\alpha$ inhibits proinflammatory mediators by interfering with the transactivation activity of $\mathrm{NF} \kappa \mathrm{B}$ and $\mathrm{AP}-1$, the main transcription factors mediating inflammatory and growth factor responses. $\operatorname{PPAR} \alpha$ via direct protein-protein interactions can bind and inhibit the actions p65 and c-jun subunits, respectively $[95,96]$.

Although the weight of evidence points towards an anti-inflammatory role for $\operatorname{PPAR} \alpha$, oxidised lipids that can activate $\operatorname{PPAR} \alpha$ have been shown to increase the release of

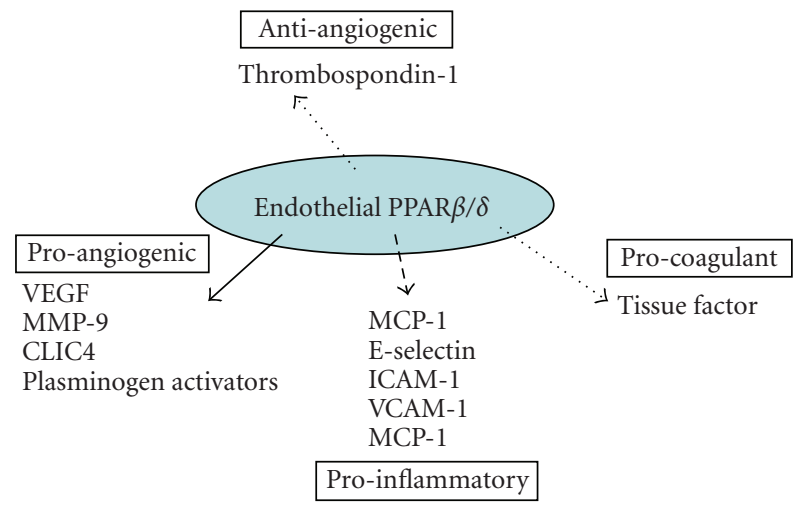

FIgURE 4: Endothelial PPAR $\beta / \delta$ has predominantly proangiogenic actions on endothelial cells. The majority of studies so far indicate that $\mathrm{PPAR} \beta / \delta$ activation induces (solid line) proangiogenic factors, while reduces (broken line) antiangiogenic factors. Similar to $\operatorname{PPAR} \alpha$ and $\operatorname{PPAR} \gamma, \operatorname{PPAR} \beta / \delta$ also appears to be anti-inflammatory by reducing proinflammatory pathways and potentially anticoagulant by reducing tissue factor release.

neutrophil chemoattractant IL- 8 and MCP-1 from endothelial cells [30]. Similarly, PPAR $\alpha$ ligands induce COX-2 in human breast and colon cancer cells $[97,98]$.

$\operatorname{PPAR} \gamma$, similarly, is a well-established negative regulator of the inflammatory response in vitro and in vivo [34]. PPAR $\gamma$ agonists have been shown to mediate effects on cell survival, surface-protein expression, and cytokine and chemokine production. In endothelial cells, PPAR $\gamma$ ligands can induce apoptosis [27] and decrease inflammatory cell recruitment by inhibiting the production of chemokines IL8, MCP-1 [30, 99], IP-10, Mig, and I-TAC [100] and reducing ICAM-1 expression [101]. Similar to PPAR- $\alpha$, PPAR $\gamma$ ligands repress thrombin-induced expression of endothelin-1 [32].

\section{4. $\operatorname{PPAR} \beta / \delta$}

\subsection{PPAR $\beta / \delta$ ligands}

$\operatorname{PPAR} \beta / \delta$ (Figure 4) is almost ubiquitously expressed [102], although compared to PPAR $\alpha$ and $-\gamma$, less is known regarding its role in the body. However, like PPAR $\alpha$ and $-\gamma$, it appears able to regulate lipid metabolism, cellular proliferation, and the inflammatory response $[55,56]$. Activators of $\operatorname{PPAR} \beta / \delta$ include a variety of eicosanoids (the COX product prostacyclin $[40,41]$, COX/prostacyclin synthasederived endocannabinoid metabolites [103]); fatty acids and synthetic compounds including GW0742X, GW501516, L165,461 , and compound $\mathrm{F}[40,41]$.

\section{2. $P P A R \beta / \delta$ and cancer}

There has recently been an increasing amount of contradictory literature published regarding $\mathrm{PPAR} \beta / \delta$ regulation of tumour cell growth and tumour cell release of VEGF. $\operatorname{PPAR} \beta / \delta$ ligands induce VEGF in bladder cancer [104], human breast (T47D, MCF7) and prostate (LNCaP, PNT1A) cancer cell lines, along with its receptor VEGFR1 [105], 
but not in colon (HT29, HCT116, LS-174T) and hepatoma (HepG2, HuH7) cell lines [106].

Much of the research into $\operatorname{PPAR} \beta / \delta$ in cancer has focused on gastrointestinal cancer. $\operatorname{PPAR} \beta / \delta$ expression is enhanced in human and rodent colorectal tumours, as well as preneoplastic colonic mucosa $[107,108] . \operatorname{PPAR} \beta / \delta$ is transcriptionally regulated by $\beta$-catenin/Tcf- 4 , which can be suppressed APC. Therefore, in colorectal cancer cells that commonly carry an APC mutation, $\operatorname{PPAR} \beta / \delta$ is upregulated [108]. Interestingly, $\operatorname{PPAR} \beta / \delta$ accumulation was localised to human colorectal carcinoma cells with a highly malignant morphology [109], suggesting PPAR $\beta / \delta$ promotes tumourogenesis. Supporting this theory, the growth of PPAR $\beta / \delta-/-$ HCT-116 human colon carcinoma cell xenografts was reduced compared to wild-type PPAR $\beta / \delta$ expressing cells [83].

Using animal models, a positive link has been made between PPAR $\beta / \delta$ and colon cancer development, especially using the intestinal polyp model, $\mathrm{APC}^{\mathrm{min}} /+$ mice. In this model, deletion of $\operatorname{PPAR} \beta / \delta$ decreases intestinal adenoma growth and inhibits the tumour-promoting effects of the $\operatorname{PPAR} \beta / \delta$ agonist GW501516 $[85,110]$. PPAR $\beta / \delta$ activation induces VEGF in colon carcinoma cells, promoting cell survival by activation of Akt signalling [85]. Angiogenesis was not studied in these experiments, however, for a tumour to grow greater than $2 \mathrm{~mm}$ in diameter a functional vessel network is required [111]. Indeed, the most prominent effect of PPAR $\beta / \delta$ activation in $\mathrm{APC}^{\mathrm{min}} /+$ mice, observed by Gupta et al., was a significant increase in the number of polyps greater than $2 \mathrm{~mm}$ in diameter [110]. Whereas there was a significant decrease in the growth of polyps greater than $2 \mathrm{~mm}$ in diameter in $\mathrm{PPAR} \beta / \delta-/-\mathrm{APC}^{\mathrm{min}} /+$ mice, despite a lack of effect on overall polyp incidence [112]; indicating that $\mathrm{PPAR} \beta / \delta$ promotes tumour growth via angiogenesis.

In contrast, deletion of $\mathrm{PPAR} \beta / \delta$ in $\mathrm{APC}^{\mathrm{min}} /+$ mice enhanced colon polyp formation in untreated mice and in mice with chemically induced colon carcinogenesis [113, 114]. The $\operatorname{PPAR} \beta / \delta$ ligand GW0742 inhibited chemically induced colon carcinogenesis in $\operatorname{PPAR} \beta / \delta$ wild-type but not $\operatorname{PPAR} \beta / \delta-/-$ mice [115]. The differences between these contrasting results have been suggested to be due to differences in genetic background, breeding, or the PPAR $\beta / \delta$ knockout strategy of the $\mathrm{APC}^{\mathrm{min}} /+$ mouse models [116]. However, this would not explain why in human colon and liver cancer cell lines, $\mathrm{PPAR} \beta / \delta$ ligands had no effect on cell growth, Akt phosphorylation, or VEGF and COX-2 expression in vitro or on these markers in the liver, colon and colon polyps in mice treated in vivo [106]. The role of $\operatorname{PPAR} \beta / \delta$ in VEGF-mediated tumourgenesis, therefore, still requires further study and clarification.

\section{3. $P P A R \beta / \delta$ and angiogenesis}

Initial reports using prostacyclin as a ligand suggested that similar to $\operatorname{PPAR} \alpha$ and $\operatorname{PPAR} \gamma, \operatorname{PPAR} \beta / \delta$ promoted endothelial cell apoptosis [117], and potentially decreased angiogenesis. In contrast, with the development of highly selective synthetic ligands, there is an increasing evidence to propose a role for $\mathrm{PPAR} \beta / \delta$ in regulating endothelial cell survival, proliferation, and angiogenesis. Indeed, treating endothelial cells with the selective PPAR $\beta / \delta$ ligand GW501516 induces proliferation, VEGF receptor (Flt-1; VEGF R1) expression, and VEGF production $[105,118]$. In addition to inducing proliferation, PPAR $\beta / \delta$ also protects the endothelial cell from oxidant injury via induction of the antiapoptotic and antiinflammatory protein 14-3-3 $\alpha$ [119].

$\operatorname{PPAR} \beta / \delta$ potently induces angiogenesis by human and murine vascular endothelial cells in tumour extracellular matrix in vitro and in a murine matrigel plug model in vivo [118]. The stimulated release of VEGF from human endothelial cells was a major trigger for morphogenesis, although mRNA for the matrix metalloproteinase (MMP)9, a protease important for cell migration, was also elevated [118]. In addition to VEGF, genomic and proteomic analysis of $\mathrm{PPAR} \beta / \delta-/-$ endothelial cells isolated from matrigel plugs identified a number of additional candidate genes that may mediate the angiogenic actions of $\operatorname{PPAR} \beta / \delta$. Cdkn1c, which encodes the cell cycle inhibitor $\mathrm{p} 57^{\mathrm{Kip} 2}$, is induced by $\operatorname{PPAR} \beta / \delta$ [120]. The chloride intracellular channel protein (CLIC)-4 is decreased in migrating endothelial cells from $\operatorname{PPAR} \beta / \delta$ knockout mice, whereas the expression of cellular retinol binding protein CRBP1 is increased [121]. CLIC-4 plays an essential role during tubular morphogenesis [122], while CRBP1 inhibits cell survival pathways by blocking the Akt signalling pathway [123]. The combination of these studies indicates that PPAR $\beta / \delta$ may induce endothelial cell mitogenesis and differentiation signals, including VEGF, 143-3 $\alpha$, CLIC4, CRBP-1, and p57 ${ }^{\mathrm{KIP} 2}$, which may combine to bring about the functional morphogenic changes associated with the angiogenic switch.

Two recent studies in particular have addressed the regulation of angiogenesis by $\mathrm{PPAR} \beta / \delta$ in matrigel plugs in $\operatorname{PPAR} \beta / \delta$ wild-type and knockout mice $[120,124]$. Xenograft tumours in PPAR $\beta / \delta-/-$ mice exhibited a diminished blood flow and immature hyperplastic microvascular structures when compared to wild-type mice. Moreover, the reintroduction of $\operatorname{PPAR} \beta / \delta$ into the matrigel plugs was able to rescue the knockout phenotype by triggering microvessel maturation [120]. In addition, tumour angiogenesis and growth are markedly inhibited in $\operatorname{PPAR} \beta / \delta-/-$ mouse models of subcutaneous Lewis lung carcinoma and B16 melanoma. $\operatorname{PPAR} \beta / \delta$ expression correlated with advanced pathological tumour stage and increased risk for tumour recurrence and distant metastasis in pancreatic tumours from patients who had undergone the "angiogenic switch" [124]. PPAR $\beta / \delta$ has, therefore, been suggested as a "hub node" transcription factor, regulating the tumour angiogenic switch [124].

\subsection{The effects of PPAR $\gamma \beta / \delta$ on endothelial progenitor cells}

Little is known about the effects of PPAR $\beta / \delta$ on EPCs, but there is one study that shows that $\operatorname{PPAR} \beta / \delta$ is a key regulator of EPC proangiogenic functions. Prostacyclin is a putative $\operatorname{PPAR} \beta / \delta$ ligand and proangiogenic factor, produced by COX and $\mathrm{PGI}_{2}$ synthase in the endothelium. EPC tube formation 
and proliferation are induced by the selective $\operatorname{PAAR} \beta / \delta$ ligand GW510516. EPCs treated with an inhibitor of COX or COX-1, prostacyclin synthase, or PPAR $\beta / \delta$ specific siRNA, exhibit decreased cell proliferation and tube formation [125]. Thus the proangiogenic effects of human EPCs appear in part dependent on the biosynthesis of prostacyclin and the subsequent activation of $\operatorname{PPAR} \beta / \delta$.

\subsection{The effect of PPAR $\beta / \delta$ on endothelial cell inflammation}

Little is known regarding the role of $\operatorname{PPAR} \beta / \delta$ in endothelial cell inflammation and mediator secretion. $\mathrm{PPAR} \beta / \delta$ ligands, similar to $\operatorname{PPAR} \alpha$ and $\operatorname{PPAR} \gamma$ ligands, inhibit cytokinestimulated upregulation of adhesion molecules ICAM-1, VCAM-1, and e-selectin and NF $\kappa$ B translocation [126, 127]. These anti-inflammatory effects of $\operatorname{PPAR} \beta / \delta$ in endothelial cells occur when the complex between PPAR $\beta / \delta$ and the transcriptional repressor BCL6 is removed by ligand activation, identical to the mechanism identified in monocytes [128]. PPAR $\beta / \delta$ and BCL6 are then free to act on PPAR $\beta / \delta$ targets (including SOD and catalase) and BCL6 targets which importantly include the repression of $\mathrm{NF} \kappa \mathrm{B}$. In addition to anti-inflammatory effects, endogenous $\operatorname{PPAR} \beta / \delta$ ligands are continuously produced in endothelial cells to suppress the release of tissue factor, the primary initiator of coagulation [103].

\section{PPAR THERAPY FOR CANCER}

The PPARs have pleiotrophic actions on nonvascular and vascular cells. PPAR $\alpha$ and PPAR $\gamma$ ligands (although there are well-detailed current concerns for rosiglitazone) are in clinical use, are considered safe, and have high tolerability with chronic use. There is considerable evidence that PPAR $\gamma$ and increasing evidence that $\operatorname{PPAR} \alpha$ are vascular protective and reduce angiogenesis. Unfortunately, as yet, there is a little clinical evidence to support these actions, apart from the promising results with the PPAR $\gamma$ ligand troglitazone in liposarcoma and prostate cancer previously mentioned [64, 65]. Clinically, $\operatorname{PPAR} \alpha$ and $\gamma$ ligands do not appear to be strong antiangiogenic drugs. However, since PPAR $\alpha$ and PPAR $y$ ligands are in clinical use and lack severe side effects, the potential for their use to complement or augment current and new therapies to treat a variety of cancers is currently being tested in small scale trials. For example, a phase II trial combining anti-inflammatory and angiostatic therapy (PPAR $\gamma$ ligand pioglitazone and COX-2 inhibitor, rofecoxib) with metronomic low-dose chemotherapy (trofosamide) found that the progression-free survival rates of advanced melanoma patients were longer with the combination treatment than with metronomic chemotherapy alone [129]. This combination therapy was also successful in achieving disease stabilization or remission in patients with advanced progressive malignant vascular tumours [130] and partial remission in a single patient with endemic Kaposi sarcoma [131]. However, a similar phase II study on high-grade glioma patients, showed disease stabilisation in only 4 out of 14 patients, suggesting that this combined therapy may only be suitable for a subset of patients [132]. The COX-2 inhibitor rofecoxib was included in the trial because COX-2 plays a role in endothelial tube formation, pericyte recruitment, and endothelial cell survival during early angiogenesis [133]. As $\operatorname{PPAR} \alpha$ and $\gamma$ ligands have been shown to inhibit COX-2 induction in endothelial cells, it would be interesting to test the combined effects of PPAR $\alpha$ or $-\gamma$ ligands with metronomic chemotherapy alone.

In contrast to $\operatorname{PPAR} \alpha$ and $\operatorname{PPAR} \gamma$, there is increasing evidence that $\operatorname{PPAR} \beta / \delta$ is proangiogenic and an important transcription factor in the angiogenic switch. $\mathrm{PPAR} \beta / \delta$ has an interesting activity profile in that like the other PPARs it also appears to have anti-inflammatory properties. As $\operatorname{PPAR} \beta / \delta$ is considered a target to treat dyslipidaemia, its proangiogenic properties should, therefore, be considered in the long-term use of $\mathrm{PPAR} \beta / \delta$ ligands to treat chronic metabolic diseases. The development of selective antagonists for $\operatorname{PPAR} \beta / \delta$ offers great potential for cancer treatment. One such antagonist has recently been identified, GSK0660, which can compete with agonist in a cellular context and by itself exhibits inverse agonist activity [134]. This antagonist appears to act by promoting $\operatorname{PPAR} \beta / \delta$-mediated repression of gene expression. Unfortunately, this compound lacks in vivo bioavailability, but will be a valuable tool for elucidating the role of $\operatorname{PPAR} \beta / \delta$ in cancer and angiogenesis in vitro and a basis for further development of a selective bioavailable PPAR $\beta / \delta$ antagonist [134]. Selective modulators of $\operatorname{PPAR} \beta / \delta$, which maintain the beneficial metabolic (and anti-inflammatory) effects while exerting no proangiogenic effects would also be beneficial. Interestingly, there is a newly developed PPAR- $\alpha$ agonist (R)-K-13675, which inhibits the secretion of inflammatory markers without affecting cell proliferation or endothelial tube formation [135], which suggests that selective modulators for the other PPARs may soon be available.

\section{REFERENCES}

[1] J. Folkman, "Role of angiogenesis in tumor growth and metastasis," Seminars in Oncology, vol. 29, no. 6, supplement 16, pp. 15-18, 2002.

[2] J. Folkman, "Fundamental concepts of the angiogenic process," Current Molecular Medicine, vol. 3, no. 7, pp. 643-651, 2003.

[3] J. Folkman, "Angiogenesis and apoptosis," Seminars in Cancer Biology, vol. 13, no. 2, pp. 159-167, 2003.

[4] J. Folkman, "Angiogenesis," Annual Review of Medicine, vol. 57, pp. 1-18, 2006.

[5] C. Blancher, J. W. Moore, K. L. Talks, S. Houlbrook, and A. L. Harris, "Relationship of hypoxia-inducible factor (HIF)- $1 \alpha$ and HIF- $2 \alpha$ expression to vascular endothelial growth factor induction and hypoxia survival in human breast cancer cell lines," Cancer Research, vol. 60, no. 24, pp. 7106-7113, 2000.

[6] H. H. Marti, "Angiogenesis—a self-adapting principle in hypoxia," EXS, no. 94, pp. 163-180, 2005.

[7] P. H. Maxwell and P. J. Ratcliffe, "Oxygen sensors and angiogenesis," Seminars in Cell \& Developmental Biology, vol. 13, no. 1, pp. 29-37, 2002.

[8] G. L. Wang and G. L. Semenza, "General involvement of hypoxia-inducible factor 1 in transcriptional response to hypoxia," Proceedings of the National Academy of Sciences of 
the United States of America, vol. 90, no. 9, pp. 4304-4308, 1993.

[9] M. Presta, P. Dell'Era, S. Mitola, E. Moroni, R. Ronca, and M. Rusnati, "Fibroblast growth factor/fibroblast growth factor receptor system in angiogenesis," Cytokine \& Growth Factor Reviews, vol. 16, no. 2, pp. 159-178, 2005.

[10] D. Ribatti, M. T. Conconi, and G. G. Nussdorfer, "Nonclassic endogenous novel regulators of angiogenesis," Pharmacological Reviews, vol. 59, no. 2, pp. 185-205, 2007.

[11] J. Folkman, "Antiangiogenesis in cancer therapy—endostatin and its mechanisms of action," Experimental Cell Research, vol. 312, no. 5, pp. 594-607, 2006.

[12] G. N. Naumov, E. Bender, D. Zurakowski, et al., "A model of human tumor dormancy: an angiogenic switch from the nonangiogenic phenotype," Journal of the National Cancer Institute, vol. 98, no. 5, pp. 316-325, 2006.

[13] A. Hoeben, B. Landuyt, M. S. Highley, H. Wildiers, A. T. Van Oosterom, and E. A. De Bruijn, "Vascular endothelial growth factor and angiogenesis," Pharmacological Reviews, vol. 56, no. 4, pp. 549-580, 2004.

[14] L. Chang, A. Kaipainen, and J. Folkman, "Lymphangiogenesis: new mechanisms," Annals of the New York Academy of Sciences, vol. 979, pp. 111-119, 2002.

[15] C. Wissmann and M. Detmar, "Pathways targeting tumor lymphangiogenesis," Clinical Cancer Research, vol. 12, no. 23, pp. 6865-6868, 2006.

[16] L. Ying and L. J. Hofseth, "An emerging role for endothelial nitric oxide synthase in chronic inflammation and cancer," Cancer Research, vol. 67, no. 4, pp. 1407-1410, 2007.

[17] K. E. de Visser, A. Eichten, and L. M. Coussens, "Paradoxical roles of the immune system during cancer development," Nature Reviews Cancer, vol. 6, no. 1, pp. 24-37, 2006.

[18] E. Y. Lin and J. W. Pollard, "Role of infiltrated leucocytes in tumour growth and spread," British Journal of Cancer, vol. 90, no. 11, pp. 2053-2058, 2004.

[19] M. Karin, "Nuclear factor- $\kappa \mathrm{B}$ in cancer development and progression," Nature, vol. 441, no. 7092, pp. 431-436, 2006.

[20] V. W. M. van Hinsbergh, "The endothelium: vascular control of haemostasis," European Journal of Obstetrics Gynecology and Reproductive Biology, vol. 95, no. 2, pp. 198-201, 2001.

[21] S. Gross, P. Tilly, D. Hentsch, J.-L. Vonesch, and J.-E. Fabre, "Vascular wall-produced prostaglandin E2 exacerbates arterial thrombosis and atherothrombosis through platelet EP3 receptors," Journal of Experimental Medicine, vol. 204, no. 2, pp. 311-320, 2007.

[22] T. Hla and K. Neilson, "Human cyclooxygenase-2 cDNA," Proceedings of the National Academy of Sciences of the United States of America, vol. 89, no. 16, pp. 7384-7388, 1992.

[23] D. Feinbloom and K. A. Bauer, "Assessment of hemostatic risk factors in predicting arterial thrombotic events," Arteriosclerosis, Thrombosis, and Vascular Biology, vol. 25, no. 10, pp. 2043-2053, 2005.

[24] E. Sierko and M. Z. Wojtukiewicz, "Inhibition of platelet function: does it offer a chance of better cancer progression control?" Seminars in Thrombosis and Hemostasis, vol. 33, no. 7, pp. 712-721, 2007.

[25] M. L. Nierodzik and S. Karpatkin, "Thrombin induces tumor growth, metastasis, and angiogenesis: evidence for a thrombin-regulated dormant tumor phenotype," Cancer Cell, vol. 10, no. 5, pp. 355-362, 2006.

[26] G. P. Gupta and J. Massagué, "Cancer metastasis: building a framework," Cell, vol. 127, no. 4, pp. 679-695, 2006.

[27] D. Bishop-Bailey and T. Hla, "Endothelial cell apoptosis induced by the peroxisome proliferator-activated receptor
(PPAR) ligand 15-deoxy- $\Delta^{12,14}$-prostaglandin $\mathrm{J}_{2}$," The Journal of Biological Chemistry, vol. 274, no. 24, pp. 17042-17048, 1999.

[28] X. Xin, S. Yang, J. Kowalski, and M. E. Gerritsen, "Peroxisome proliferator-activated receptor $\gamma$ ligands are potent inhibitors of angiogenesis in vitro and in vivo," The Journal of Biological Chemistry, vol. 274, no. 13, pp. 9116-9121, 1999.

[29] S. M. Jackson, F. Parhami, X.-P. Xi, et al., "Peroxisome proliferator-activated receptor activators target human endothelial cells to inhibit leukocyte-endothelial cell interaction," Arteriosclerosis, Thrombosis, and Vascular Biology, vol. 19, no. 9, pp. 2094-2104, 1999.

[30] H. Lee, W. Shi, P. Tontonoz, et al., "Role for peroxisome proliferator-activated receptor $\alpha$ in oxidized phospholipidinduced synthesis of monocyte chemotactic protein-1 interleukin-8 by endothelial cells," Circulation Research, vol. 87, no. 6, pp. 516-521, 2000.

[31] N. Marx, T. Bourcier, G. K. Sukhova, P. Libby, and J. Plutzky, "PPAR $\gamma$ activation in human endothelial cells increases plasminogen activator inhibitor type-1 expression: PPAR $\gamma$ as a potential mediator in vascular disease," Arteriosclerosis, Thrombosis, and Vascular Biology, vol. 19, no. 3, pp. 546-551, 1999.

[32] P. Delerive, F. Martin-Nizard, G. Chinetti, et al., "Peroxisome proliferator-activated receptor activators inhibit thrombin-induced endothelin-1 production in human vascular endothelial cells by inhibiting the activator protein-1 signaling pathway," Circulation Research, vol. 85, no. 5, pp. 394-402, 1999.

[33] C. Giaginis, A. Margeli, and S. Theocharis, "Peroxisome proliferator-activated receptor- $\gamma$ ligands as investigational modulators of angiogenesis," Expert Opinion on Investigational Drugs, vol. 16, no. 10, pp. 1561-1572, 2007.

[34] L. A. Moraes, L. Piqueras, and D. Bishop-Bailey, "Peroxisome proliferator-activated receptors and inflammation," Pharmacology \& Therapeutics, vol. 110, no. 3, pp. 371-385, 2006.

[35] C. Grommes, G. E. Landreth, and M. T. Heneka, "Antineoplastic effects of peroxisome proliferator-activated receptor $\gamma$ agonists," Lancet Oncology, vol. 5, no. 7, pp. 419-429, 2004.

[36] C. Giaginis, A. Tsantili-Kakoulidou, and S. Theocharis, "Peroxisome proliferator-activated receptor- $\gamma$ ligands: potential pharmacological agents for targeting the angiogenesis signaling cascade in cancer," PPAR Research, vol. 2008, Article ID 431763, 12 pages, 2008.

[37] F. Akbiyik, D. M. Ray, K. F. Gettings, N. Blumberg, C. W. Francis, and R. P. Phipps, "Human bone marrow megakaryocytes and platelets express $\operatorname{PPAR} \gamma$, and $\operatorname{PPAR} \gamma$ agonists blunt platelet release of CD40 ligand and thromboxanes," Blood, vol. 104, no. 5, pp. 1361-1368, 2004.

[38] F. Y. Ali, S. J. Davidson, L. A. Moraes, et al., "Role of nuclear receptor signaling in platelets: antithrombotic effects of PPAR $\beta$," The FASEB Journal, vol. 20, no. 2, pp. 326-328, 2006.

[39] L. A. Moraes, K. E. Swales, J. A. Wray, et al., "Nongenomic signaling of the retinoid $\mathrm{X}$ receptor through binding and inhibiting Gq in human platelets," Blood, vol. 109, no. 9, pp. 3741-3744, 2007.

[40] D. Bishop-Bailey, "Peroxisome proliferator-activated receptors in the cardiovascular system," British Journal of Pharmacology, vol. 129, no. 5, pp. 823-834, 2000.

[41] D. Bishop-Bailey and J. Wray, "Peroxisome proliferatoractivated receptors: a critical review on endogenous pathways for ligand generation," Prostaglandins and Other Lipid Mediators, vol. 71, no. 1-2, pp. 1-22, 2003. 
[42] F. J. Gonzalez and Y. M. Shah, "PPAR $\alpha$ : mechanism of species differences and hepatocarcinogenesis of peroxisome proliferators," Toxicology, vol. 246, no. 1, pp. 2-8, 2008.

[43] J. M. Peters, C. Cheung, and F. J. Gonzalez, "Peroxisome proliferator-activated receptor- $\alpha$ and liver cancer: where do we stand?" Journal of Molecular Medicine, vol. 83, no. 10, pp. 774-785, 2005.

[44] K. Hanley, Y. Jiang, S. S. He, et al., "Keratinocyte differentiation is stimulated by activators of the nuclear hormone receptor PPAR $\alpha$," Journal of Investigative Dermatology, vol. 110, no. 4, pp. 368-375, 1998.

[45] L. G. Kömüves, K. Hanley, M.-Q. Man, P. M. Elias, M. L. Williams, and K. R. Feingold, "Keratinocyte differentiation in hyperproliferative epidermis: topical application of PPAR $\alpha$ activators restores tissue," Journal of Investigative Dermatology, vol. 115, no. 3, pp. 361-367, 2000.

[46] P. Thuillier, G. J. Anchiraico, K. P. Nickel, et al., "Activators of peroxisome proliferator-activated receptor- $\alpha$ partially inhibit mouse skin tumor promotion," Molecular Carcinogenesis, vol. 29, no. 3, pp. 134-142, 2000.

[47] G. P. Collett, A. M. Betts, M. I. Johnson, et al., "Peroxisome proliferator-activated receptor $\alpha$ is an androgen-responsive gene in human prostate and is highly expressed in prostatic adenocarcinoma," Clinical Cancer Research, vol. 6, no. 8, pp. 3241-3248, 2000.

[48] D. Panigrahy, A. Kaipainen, S. Huang, et al., "PPAR $\alpha$ agonist fenofibrate suppresses tumor growth through direct and indirect angiogenesis inhibition," Proceedings of the National Academy of Sciences of the United States of America, vol. 105, no. 3, pp. 985-990, 2008.

[49] K. M. Suchanek, F. J. May, J. A. Robinson, et al., "Peroxisome proliferator-activated receptor $\alpha$ in the human breast cancer cell lines MCF-7 and MDA-MB-231," Molecular Carcinogenesis, vol. 34, no. 4, pp. 165-171, 2002.

[50] M. Grabacka, W. Placha, P. M. Plonka, et al., "Inhibition of melanoma metastases by fenofibrate," Archives of Dermatological Research, vol. 296, no. 2, pp. 54-58, 2004.

[51] S. A. Saidi, C. M. Holland, D. S. Charnock-Jones, and S. K. Smith, "In vitro and in vivo effects of the PPAR-alpha agonists fenofibrate and retinoic acid in endometrial cancer," Molecular Cancer, vol. 5, article 13, pp. 1-14, 2006.

[52] T. Tanaka, H. Kohno, S.-I. Yoshitani, et al., "Ligands for peroxisome proliferator-activated receptors $\alpha$ and $\gamma$ inhibit chemically induced colitis and formation of aberrant crypt foci in rats," Cancer Research, vol. 61, no. 6, pp. 2424-2428, 2001.

[53] Y. Yokoyama, B. Xin, T. Shigeto, et al., "Clofibric acid, a peroxisome proliferator-activated receptor $\alpha$ ligand, inhibits growth of human ovarian cancer," Molecular Cancer Therapeutics, vol. 6, no. 4, pp. 1379-1386, 2007.

[54] M. Grabacka, P. M. Plonka, K. Urbanska, and K. Reiss, "Peroxisome proliferator-activated receptor $\alpha$ activation decreases metastatic potential of melanoma cells in vitro via down-regulation of Akt," Clinical Cancer Research, vol. 12, no. 10, pp. 3028-3036, 2006.

[55] L. Michalik, J. Auwerx, J. P. Berger, et al., "International union of pharmacology. LXI. Peroxisome proliferatoractivated receptors," Pharmacological Reviews, vol. 58, no. 4, pp. 726-741, 2006.

[56] L. Michalik and W. Wahli, "Peroxisome proliferator-activated receptors (PPARs) in skin health, repair and disease," Biochimica et Biophysica Acta, vol. 1771, no. 8, pp. 991-998, 2007.
[57] R. A. Gupta and R. N. Dubois, "Controversy: PPARgamma as a target for treatment of colorectal cancer," American Journal of Physiology, vol. 283, no. 2, pp. G266-G269, 2002.

[58] A.-M. Lefebvre, I. Chen, P. Desreumaux, et al., "Activation of the peroxisome proliferator-activated receptor $\gamma$ promotes the development of colon tumors in C57BL/6J-APC ${ }^{M i n} /+$ mice," Nature Medicine, vol. 4, no. 9, pp. 1053-1057, 1998.

[59] E. Saez, P. Tontonoz, M. C. Nelson, et al., "Activators of the nuclear receptor PPAR $\gamma$ enhance colon polyp formation," Nature Medicine, vol. 4, no. 9, pp. 1058-1061, 1998.

[60] G. D. Girnun, W. M. Smith, S. Drori, et al., "APC-dependent suppression of colon carcinogenesis by PPAR $\gamma$," Proceedings of the National Academy of Sciences of the United States of America, vol. 99, no. 21, pp. 13771-13776, 2002.

[61] P. Sarraf, E. Mueller, W. M. Smith, et al., "Loss-of-function mutations in PPAR $y$ associated with human colon cancer," Molecular Cell, vol. 3, no. 6, pp. 799-804, 1999.

[62] S. Tomita, H. Kawamata, J. Imura, F. Omotehara, Y. Ueda, and T. Fujimori, "Frequent polymorphism of peroxisome proliferator activated receptor gamma gene in colorectal cancer containing wild-type K-ras gene," International Journal of Molecular Medicine, vol. 9, no. 5, pp. 485-488, 2002.

[63] M. A. K. Rumi, S. Ishihara, H. Kazumori, Y. Kadowaki, and Y. Kinoshita, "Can PRAR $\gamma$ ligands be used in cancer therapy?" Current Medicinal Chemistry - Anti-Cancer Agents, vol. 4, no. 6, pp. 465-477, 2004.

[64] E. Mueller, M. Smith, P. Sarraf, et al., "Effects of ligand activation of peroxisome proliferator-activated receptor $\gamma$ in human prostate cancer," Proceedings of the National Academy of Sciences of the United States of America, vol. 97, no. 20, pp. 10990-10995, 2000.

[65] G. D. Demetri, C. D. M. Fletcher, E. Mueller, et al., "Induction of solid tumor differentiation by the peroxisome proliferatoractivated receptor- $\gamma$ ligand troglitazone in patients with liposarcoma," Proceedings of the National Academy of Sciences of the United States of America, vol. 96, no. 7, pp. 3951-3956, 1999.

[66] G. Debrock, V. Vanhentenrijk, R. Sciot, M. Debiec-Rychter, R. Oyen, and A. Van Oosterom, "A phase II trial with rosiglitazone in liposarcoma patients," British Journal of Cancer, vol. 89, no. 8, pp. 1409-1412, 2003.

[67] J. Varet, L. Vincent, P. Mirshahi, et al., "Fenofibrate inhibits angiogenesis in vitro and in vivo," Cellular and Molecular Life Sciences, vol. 60, no. 4, pp. 810-819, 2003.

[68] T. Kasai, K. Miyauchi, T. Yokoyama, K. Aihara, and H. Daida, "Efficacy of peroxisome proliferative activated receptor (PPAR)- $\alpha$ ligands, fenofibrate, on intimal hyperplasia and constrictive remodeling after coronary angioplasty in porcine models," Atherosclerosis, vol. 188, no. 2, pp. 274-280, 2006.

[69] O. Sato, C. Kuriki, Y. Fukui, and K. Motojima, "Dual promoter structure of mouse and human fatty acid translocase/CD36 genes and unique transcriptional activation by peroxisome proliferator-activated receptor $\alpha$ and $\gamma$ ligands," The Journal of Biological Chemistry, vol. 277, no. 18, pp. 15703-15711, 2002.

[70] I. Jedidi, M. Couturier, P. Thérond, et al., "Cholesteryl ester hydroperoxides increase macrophage CD36 gene expression via PPAR $\alpha$," Biochemical and Biophysical Research Communications, vol. 351, no. 3, pp. 733-738, 2006.

[71] H. Huang, S. C. Campbell, D. F. Bedford, et al., "Peroxisome proliferator-activated receptor $\gamma$ ligands improve the antitumor efficacy of thrombospondin peptide ABT510," Molecular Cancer Research, vol. 2, no. 10, pp. 541-550, 2004. 
[72] F. Biscetti, E. Gaetani, A. Flex, et al., "Selective activation of PPAR $\alpha$ and PPAR $\gamma$ induces neoangiogenesis through a VEGF-dependent mechanism," Diabetes, vol. 57, no. 5, pp. 1394-1404, 2008.

[73] V. Chintalgattu, G. S. Harris, S. M. Akula, and L. C. Katwa, "PPAR- $\gamma$ agonists induce the expression of VEGF and its receptors in cultured cardiac myofibroblasts," Cardiovascular Research, vol. 74, no. 1, pp. 140-150, 2007.

[74] S. Kanata, M. Akagi, S. Nishimura, et al., "Oxidized LDL binding to LOX-1 upregulates VEGF expression in cultured bovine chondrocytes through activation of PPAR- $\gamma$," Biochemical and Biophysical Research Communications, vol. 348, no. 3, pp. 1003-1010, 2006.

[75] K. Yamakawa, M. Hosoi, H. Koyama, et al., "Peroxisome proliferator-activated receptor- $\gamma$ agonists increase vascular endothelial growth factor expression in human vascular smooth muscle cells," Biochemical and Biophysical Research Communications, vol. 271, no. 3, pp. 571-574, 2000.

[76] M. A. Sarayba, L. Li, T. Tungsiripat, et al., "Inhibition of corneal neovascularization by a peroxisome proliferatoractivated receptor- $\gamma$ ligand," Experimental Eye Research, vol. 80, no. 3, pp. 435-442, 2005.

[77] L. L. H. Peeters, J.-L. Vigne, M. K. Tee, D. Zhao, L. L. Waite, and R. N. Taylor, "PPAR $y$ represses VEGF expression in human endometrial cells: implications for uterine angiogenesis," Angiogenesis, vol. 8, no. 4, pp. 373-379, 2006.

[78] B. Xin, Y. Yokoyama, T. Shigeto, M. Futagami, and H. Mizunuma, "Inhibitory effect of meloxicam, a selective cyclooxygenase- 2 inhibitor, and ciglitazone, a peroxisome proliferator-activated receptor gamma ligand, on the growth of human ovarian cancers," Cancer, vol. 110, no. 4, pp. 791800, 2007.

[79] Y. Sassa, Y. Hata, L. P. Aiello, Y. Taniguchi, K. Kohno, and T. Ishibashi, "Bifunctional properties of peroxisome proliferator-activated receptor $\gamma 1$ in KDR gene regulation mediated via interaction with both Sp1 and Sp3," Diabetes, vol. 53, no. 5, pp. 1222-1229, 2004.

[80] R. Grau, C. Punzón, M. Fresno, and M. A. Iñiguez, "Peroxisome-proliferator-activated receptor $\alpha$ agonists inhibit cyclo-oxygenase 2 and vascular endothelial growth factor transcriptional activation in human colorectal carcinoma cells via inhibition of activator protein-1," Biochemical Journal, vol. 395, no. 1, pp. 81-88, 2006.

[81] F. Pistrosch, K. Herbrig, U. Oelschlaegel, et al., "PPAR $\gamma$ agonist rosiglitazone increases number and migratory activity of cultured endothelial progenitor cells," Atherosclerosis, vol. 183, no. 1, pp. 163-167, 2005.

[82] C.-H. Wang, M.-K. Ting, S. Verma, et al., "Pioglitazone increases the numbers and improves the functional capacity of endothelial progenitor cells in patients with diabetes mellitus," American Heart Journal, vol. 152, no. 6, pp. 1051.e1-1051.e8, 2006.

[83] C.-H. Wang, N. Ciliberti, S.-H. Li, et al., "Rosiglitazone facilitates angiogenic progenitor cell differentiation toward endothelial lineage: a new paradigm in glitazone pleiotropy," Circulation, vol. 109, no. 11, pp. 1392-1400, 2004.

[84] C. Werner, C. H. Kamani, C. Gensch, M. Böhm, and U. Laufs, "The peroxisome proliferator-activated receptor- $\gamma$ agonist pioglitazone increases number and function of endothelial progenitor cells in patients with coronary artery disease and normal glucose tolerance," Diabetes, vol. 56, no. 10, pp. 2609 2615, 2007.
[85] D. Wang, H. Wang, Y. Guo, et al., "Crosstalk between peroxisome proliferator-activated receptor $\delta$ and VEGF stimulates cancer progression," Proceedings of the National Academy of Sciences of the United States of America, vol. 103, no. 50, pp. 19069-19074, 2006.

[86] C. Gensch, Y. P. Clever, C. Werner, M. Hanhoun, M. Böhm, and U. Laufs, "The PPAR- $\gamma$ agonist pioglitazone increases neoangiogenesis and prevents apoptosis of endothelial progenitor cells," Atherosclerosis, vol. 192, no. 1, pp. 67-74, 2007.

[87] S. Redondo, M. Hristov, D. Gümbel, T. Tejerina, and C. Weber, "Biphasic effect of pioglitazone on isolated human endothelial progenitor cells: involvement of peroxisome proliferator-activated receptor- $\gamma$ and transforming growth factor- $\beta 1$," Thrombosis and Haemostasis, vol. 97, no. 6, pp. 979-987, 2007.

[88] P. R. Devchand, H. Keller, J. M. Peters, M. Vazquez, F. J. Gonzalez, and W. Wahli, "The PPAR $\alpha$-leukotriene B4 pathway to inflammation control," Nature, vol. 384, no. 6604, pp. 39-43, 1996.

[89] J. B. Muhlestein, H. T. May, J. R. Jensen, et al., "The reduction of inflammatory biomarkers by statin, fibrate, and combination therapy among diabetic patients with mixed dyslipidemia. The DIACOR (Diabetes and Combined Lipid Therapy Regimen) study," Journal of the American College of Cardiology, vol. 48, no. 2, pp. 396-401, 2006.

[90] T.-D. Wang, W.-J. Chen, J.-W. Lin, C.-C. Cheng, M.-F. Chen, and Y.-T. Lee, "Efficacy of fenofibrate and simvastatin on endothelial function and inflammatory markers in patients with combined hyperlipidemia: relations with baseline lipid profiles," Atherosclerosis, vol. 170, no. 2, pp. 315-323, 2003.

[91] S. Cuzzocrea, R. Di Paola, E. Mazzon, T. Genovese, C. Muià, and A. P. Caputi, "WY 14643, a potent exogenous PPAR- $\alpha$ ligand, reduces intestinal injury associated with splanchnic artery occlusion shock," Shock, vol. 22, no. 4, pp. 340-346, 2004.

[92] F. Martin-Nizard, S. Sahpaz, A. Kandoussi, et al., "Natural phenylpropanoids inhibit lipoprotein-induced endothelin1 secretion by endothelial cells," Journal of Pharmacy and Pharmacology, vol. 56, no. 12, pp. 1607-1611, 2004.

[93] B. Staels, W. Koenig, A. Habib, et al., "Activation of human aortic smooth-muscle cells is inhibited by PPAR $\alpha$ but not by PPAR $\gamma$ activators," Nature, vol. 393, no. 6687, pp. 790-793, 1998.

[94] J. Golledge, S. Mangan, and P. Clancy, "Effects of peroxisome proliferator-activated receptor ligands in modulating tissue factor and tissue factor pathway inhibitor in acutely symptomatic carotid atheromas," Stroke, vol. 38, no. 5, pp. 15011508, 2007.

[95] M. Grabacka and K. Reiss, "Anticancer properties of PPAR $\alpha$ - effects on cellular metabolism and inflammation," PPAR Research, vol. 2008, Article ID 930705, 9 pages, 2008.

[96] P. Delerive, K. De Bosscher, S. Besnard, et al., "Peroxisome proliferator-activated receptor $\alpha$ negatively regulates the vascular inflammatory gene response by negative cross-talk with transcription factors NF- $\kappa \mathrm{B}$ and AP-1," The Journal of Biological Chemistry, vol. 274, no. 45, pp. 32048-32054, 1999.

[97] H. Ikawa, H. Kameda, H. Kamitani, et al., "Effect of PPAR activators on cytokine-stimulated cyclooxygenase-2 expression in human colorectal carcinoma cells," Experimental Cell Research, vol. 267, no. 1, pp. 73-80, 2001.

[98] E. A. Meade, T. M. McIntyre, G. A. Zimmerman, and S. M. Prescott, "Peroxisome proliferators enhance cyclooxygenase2 expression in epithelial cells," The Journal of Biological Chemistry, vol. 274, no. 12, pp. 8328-8334, 1999. 
[99] V. Pasceri, J. Chang, J. T. Willerson, and E. T. H. Yeh, "Modulation of C-reactive protein-mediated monocyte chemoattractant protein-1 induction in human endothelial cells by anti-atherosclerosis drugs," Circulation, vol. 103, no. 21, pp. 2531-2534, 2001

[100] N. Marx, F. Mach, A. Sauty, et al., "Peroxisome proliferatoractivated receptor- $\gamma$ activators inhibit IFN- $\gamma$-induced expression of the T cell-active CXC chemokines IP-10, Mig, and ITAC in human endothelial cells," The Journal of Immunology, vol. 164, no. 12, pp. 6503-6508, 2000.

[101] N.-G. Chen and X. Han, "Dual function of troglitazone in ICAM-1 gene expression in human vascular endothelium," Biochemical and Biophysical Research Communications, vol. 282, no. 3, pp. 717-722, 2001.

[102] S. A. Kliewer, B. M. Forman, B. Blumberg, et al., "Differential expression and activation of a family of murine peroxisome proliferator-activated receptors," Proceedings of the National Academy of Sciences of the United States of America, vol. 91, no. 15, pp. 7355-7359, 1994.

[103] M. Ghosh, H. Wang, Y. Ai, et al., "COX-2 suppresses tissue factor expression via endocannabinoid-directed PPAR $\delta$ activation," Journal of Experimental Medicine, vol. 204, no. 9, pp. 2053-2061, 2007.

[104] S. Fauconnet, I. Lascombe, E. Chabannes, et al., "Differential regulation of vascular endothelial growth factor expression by peroxisome proliferator-activated receptors in bladder cancer cells," The Journal of Biological Chemistry, vol. 277, no. 26, pp. 23534-23543, 2002.

[105] R. L. Stephen, M. C. U. Gustafsson, M. Jarvis, et al., "Activation of peroxisome proliferator-activated receptor $\delta$ stimulates the proliferation of human breast and prostate cancer cell lines," Cancer Research, vol. 64, no. 9, pp. 31623170, 2004.

[106] H. E. Hollingshead, R. L. Killins, M. G. Borland, et al., "Peroxisome proliferator-activated receptor- $\beta / \delta(\operatorname{PPAR} \beta / \delta)$ ligands do not potentiate growth of human cancer cell lines," Carcinogenesis, vol. 28, no. 12, pp. 2641-2649, 2007.

[107] R. A. Gupta, J. Tan, W. F. Krause, et al., "Prostacyclinmediated activation of peroxisome proliferator-activated receptor $\delta$ in colorectal cancer," Proceedings of the National Academy of Sciences of the United States of America, vol. 97, no. 24, pp. 13275-13280, 2000.

[108] T.-C. He, T. A. Chan, B. Vogelstein, and K. W. Kinzler, "PPAR $\delta$ is an APC-regulated target of nonsteroidal antiinflammatory drugs," Cell, vol. 99, no. 3, pp. 335-345, 1999.

[109] O. Takayama, H. Yamamoto, B. Damdinsuren, et al., "Expression of PPAR $\delta$ in multistage carcinogenesis of the colorectum: implications of malignant cancer morphology," British Journal of Cancer, vol. 95, no. 7, pp. 889-895, 2006.

[110] R. A. Gupta, D. Wang, S. Katkuri, H. Wang, S. K. Dey, and R. N. DuBois, "Activation of nuclear hormone receptor peroxisome proliferator-activated receptor- $\delta$ accelerates intestinal adenoma growth," Nature Medicine, vol. 10, no. 3, pp. 245247, 2004.

[111] S. Singh, A. Sadanandam, and R. K. Singh, "Chemokines in tumor angiogenesis and metastasis," Cancer and Metastasis Reviews, vol. 26, no. 3-4, pp. 453-467, 2007.

[112] Y. Barak, D. Liao, W. He, et al., "Effects of peroxisome proliferator-activated receptor $\delta$ on placentation, adiposity, and colorectal cancer," Proceedings of the National Academy of Sciences of the United States of America, vol. 99, no. 1, pp. 303-308, 2002.
[113] F. S. Harman, C. J. Nicol, H. E. Marin, J. M. Ward, F. J. Gonzalez, and J. M. Peters, "Peroxisome proliferatoractivated receptor- $\delta$ attenuates colon carcinogenesis," Nature Medicine, vol. 10, no. 5, pp. 481-483, 2004.

[114] K. R. Reed, O. J. Sansom, A. J. Hayes, et al., "PPAR $\delta$ status and Apc-mediated tumourigenesis in the mouse intestine," Oncogene, vol. 23, no. 55, pp. 8992-8996, 2004.

[115] H. E. Marin, M. A. Peraza, A. N. Billin, et al., "Ligand activation of peroxisome proliferator-activated receptor $\beta$ inhibits colon carcinogenesis," Cancer Research, vol. 66, no. 8, pp. 4394-4401, 2006.

[116] D. Wang and R. N. DuBois, "Peroxisome proliferatoractivated receptors and progression of colorectal cancer," PPAR Research, vol. 2008, Article ID 931074, 7 pages, 2008.

[117] T. Hatae, M. Wada, C. Yokoyama, M. Shimonishi, and T. Tanabe, "Prostacyclin-dependent apoptosis mediated by PPAR $\delta$," The Journal of Biological Chemistry, vol. 276, no. 49, pp. 46260-46267, 2001.

[118] L. Piqueras, A. R. Reynolds, K. M. Hodivala-Dilke, et al., "Activation of PPAR $\beta / \delta$ induces endothelial cell proliferation and angiogenesis," Arteriosclerosis, Thrombosis, and Vascular Biology, vol. 27, no. 1, pp. 63-69, 2007.

[119] J.-Y. Liou, S. Lee, D. Ghelani, N. Matijevic-Aleksic, and K. $\mathrm{K}$. Wu, "Protection of endothelial survival by peroxisome proliferator-activated receptor- $\delta$ mediated 14-3-3 upregulation," Arteriosclerosis, Thrombosis, and Vascular Biology, vol. 26, no. 7, pp. 1481-1487, 2006.

[120] S. Müller-Brüsselbach, M. Kömhoff, M. Rieck, et al., "Deregulation of tumor angiogenesis and blockade of tumor growth in PPAR $\beta$-deficient mice," The EMBO Journal, vol. 26, no. 15, pp. 3686-3698, 2007.

[121] J. Adamkiewicz, K. Kaddatz, M. Rieck, B. Wilke, S. MüllerBrüsselbach, and R. Müller, "Proteomic profile of mouse fibroblasts with a targeted disruption of the peroxisome proliferator activated receptor- $\beta / \delta$ gene," Proteomics, vol. 7 , no. 8, pp. 1208-1216, 2007.

[122] S. Bohman, T. Matsumoto, K. Suh, et al., "Proteomic analysis of vascular endothelial growth factor-induced endothelial cell differentiation reveals a role for chloride intracellular channel 4 (CLIC4) in tubular morphogenesis," The Journal of Biological Chemistry, vol. 280, no. 51, pp. 42397-42404, 2005.

[123] Y. S. Kuppumbatti, B. Rexer, S. Nakajo, K. Nakaya, and R. Mira-y-Lopez, "CRBP suppresses breast cancer cell survival and anchorage-independent growth," Oncogene, vol. 20, no. 50, pp. 7413-7419, 2001.

[124] A. Abdollahi, C. Schwager, J. Kleeff, et al., "Transcriptional network governing the angiogenic switch in human pancreatic cancer," Proceedings of the National Academy of Sciences of the United States of America, vol. 104, no. 31, pp. 1289012895, 2007.

[125] T. He, T. Lu, L. V. d'Uscio, C. F. Lam, H. C. Lee, and Z. S. Katusic, "Angiogenic function of prostacyclin biosynthesis in human endothelial progenitor cells," Circulation Research, vol. 103, no. 1, pp. 80-88, 2008.

[126] Y. Fan, Y. Wang, Z. Tang, et al., "Suppression of proinflammatory adhesion molecules by PPAR- $\delta$ in human vascular endothelial cells," Arteriosclerosis, Thrombosis, and Vascular Biology, vol. 28, no. 2, pp. 315-321, 2008.

[127] Y. Rival, N. Benéteau, T. Taillandier, et al., "PPAR $\alpha$ and $\operatorname{PPAR} \delta$ activators inhibit cytokine-induced nuclear translocation of NF- $\kappa \mathrm{B}$ and expression of VCAM-1 in EAhy926 endothelial cells," European Journal of Pharmacology, vol. 435, no. 2-3, pp. 143-151, 2002. 
[128] C.-H. Lee, A. Chawla, N. Urbiztondo, D. Liao, W. A. Boisvert, and R. M. Evans, "Transcriptional repression of atherogenic inflammation: modulation by $\operatorname{PPAR} \delta$," Science, vol. 302, no. 5644, pp. 453-457, 2003.

[129] A. Reichle, T. Vogt, B. Coras, et al., "Targeted combined anti-inflammatory and angiostatic therapy in advanced melanoma: a randomized phase II trial," Melanoma Research, vol. 17, no. 6, pp. 360-364, 2007.

[130] T. Vogt, C. Hafner, K. Bross, et al., "Antiangiogenetic therapy with pioglitazone, rofecoxib, and metronomic trofosfamide in patients with advanced malignant vascular tumors," Cancer, vol. 98, no. 10, pp. 2251-2256, 2003.

[131] B. Coras, C. Hafner, A. Reichle, et al., "Antiangiogenic therapy with pioglitazone, rofecoxib, and trofosfamide in a patient with endemic kaposi sarcoma," Archives of Dermatology, vol. 140, no. 12, pp. 1504-1507, 2004.

[132] P. Hau, L. Kunz-Schughart, U. Bogdahn, et al., "Low-dose chemotherapy in combination with COX-2 inhibitors and PPAR-gamma agonists in recurrent high-grade gliomas-a phase II study," Oncology, vol. 73, no. 1-2, pp. 21-25, 2008.

[133] M. F. McCarty, J. Barroso-Aranda, and F. Contreras, "PPARgamma agonists can be expected to potentiate the efficacy of metronomic chemotherapy through CD36 upregulation," Medical Hypotheses, vol. 70, no. 2, pp. 419-423, 2008.

[134] B. G. Shearer, D. J. Steger, J. M. Way, et al., "Identification and characterization of a selective peroxisome proliferatoractivated receptor $\beta / \delta$ (NR1C2) antagonist," Molecular Endocrinology, vol. 22, no. 2, pp. 523-529, 2008.

[135] K. Kitajima, S.-I. Miura, Y. Mastuo, Y. Uehara, and K. Saku, "Newly developed PPAR- $\alpha$ agonist (R)-K-13675 inhibits the secretion of inflammatory markers without affecting cell proliferation or tube formation," Atherosclerosis. In press. 


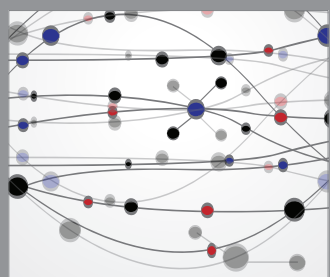

The Scientific World Journal
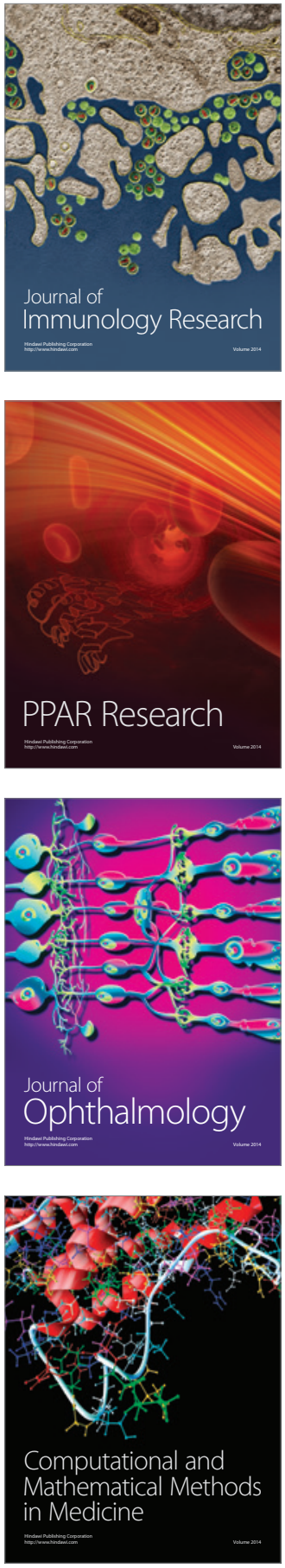

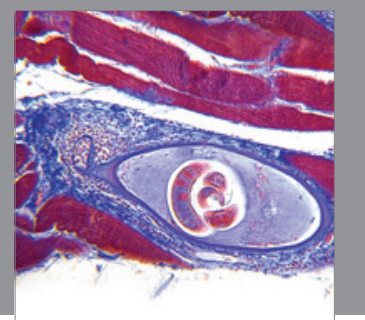

Gastroenterology

Research and Practice
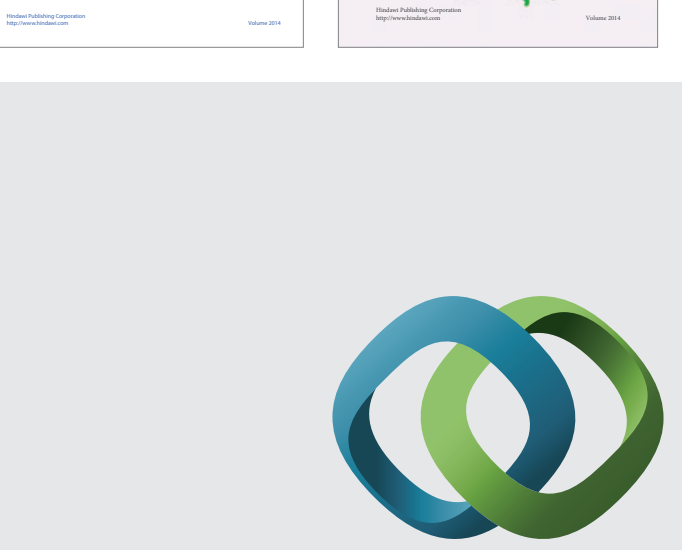

\section{Hindawi}

Submit your manuscripts at

http://www.hindawi.com
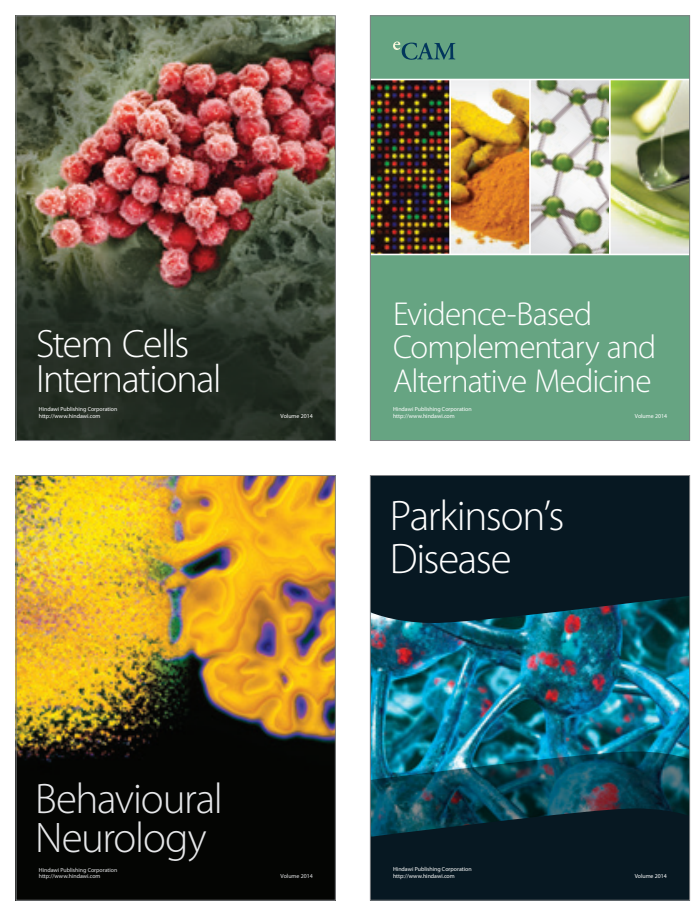

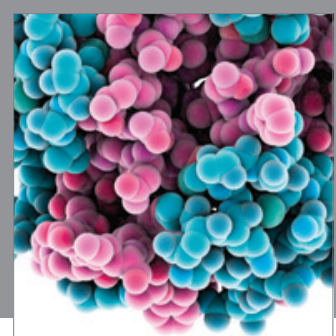

Journal of
Diabetes Research

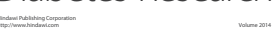

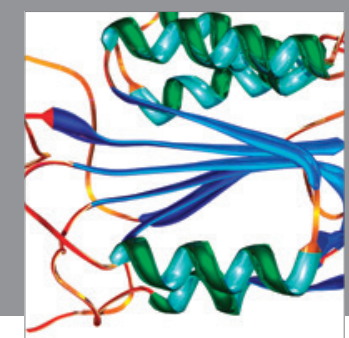

Disease Markers
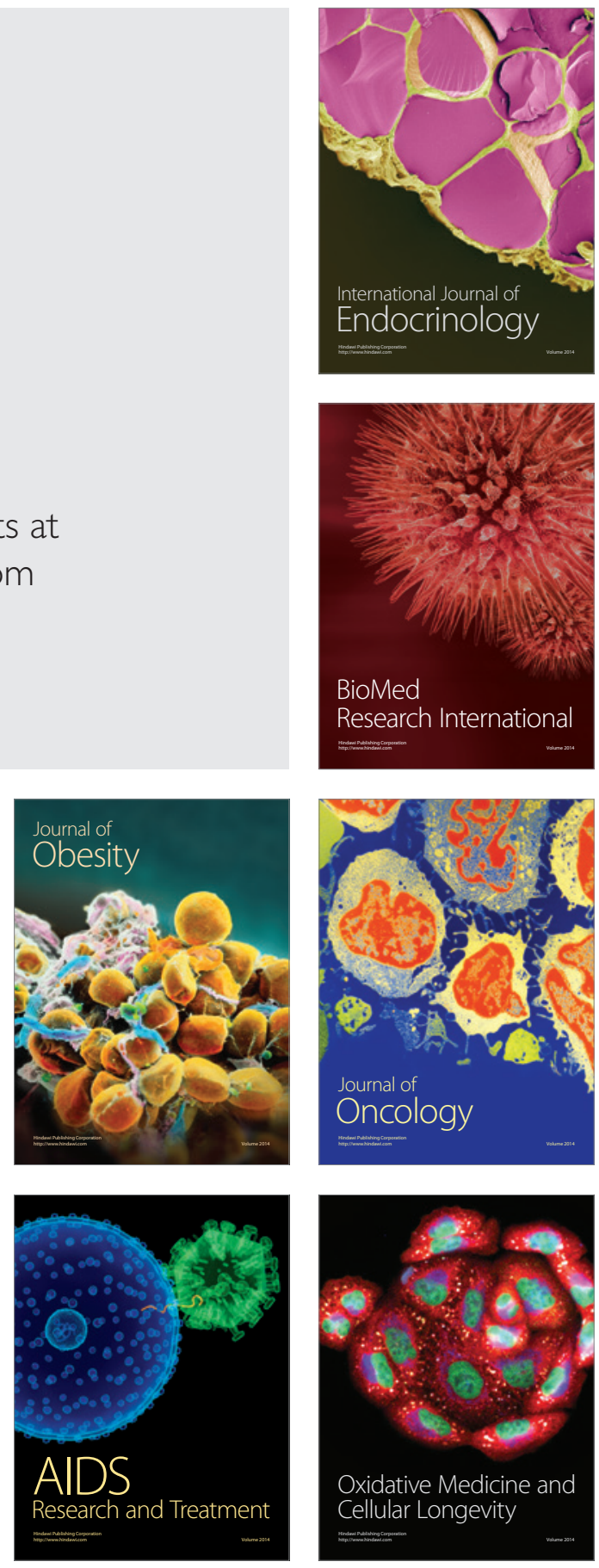